Preprints of the

Max Planck Institute for

Research on Collective Goods

Bonn 2017/14

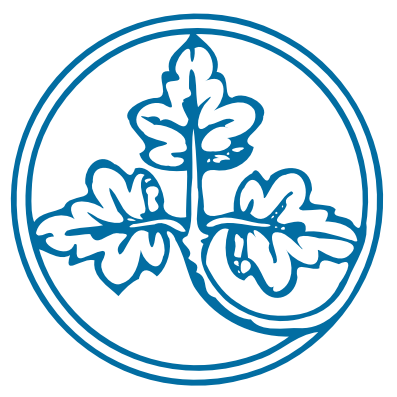

Precautionary recapitalisations: time for a review

Martin Hellwig

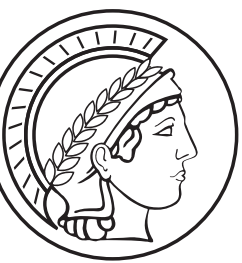




\title{
Precautionary recapitalisations: time for a review
}

\author{
Martin Hellwig
}

July 2017

This material was originally published in a paper provided at the request of the Committee on Economic and Monetary Affairs of the European Parliament and commissioned by the Directorate General for Internal Policies of the Union and supervised by its Economic Governance Support Unit (EGOV). The opinions expressed in this document are the sole responsibility of the author and do not necessarily represent the official position of the European Parliament. The original paper is available on the European Parliament's webpage http://www.europarl.europa.eu/RegData/ etudes/IDAN/2017/602089/IPOL_IDA(2017)602089_EN.pdf .

(C) European Union 2016. Copyright remains with the European Union at all times. 
IPOL $\mid$ DIRECTORATE-GENERAL FOR INTERNAL POLICIES

EGOV ECONOMIC GOVERNANCE SUPPORT UNIT

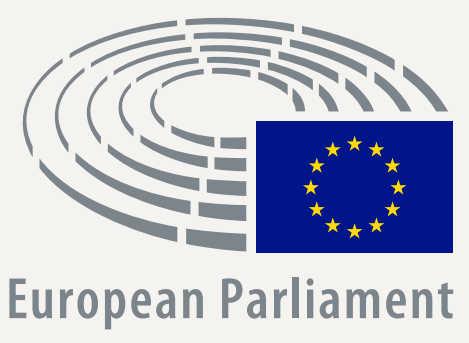

\author{
In-DePth AnALYSis
}

\title{
Precautionary recapitalisations: time for a review
}

External author:

Martin Friedrich Hellwig

Provided at the request of the Economic and Monetary Affairs Committee 


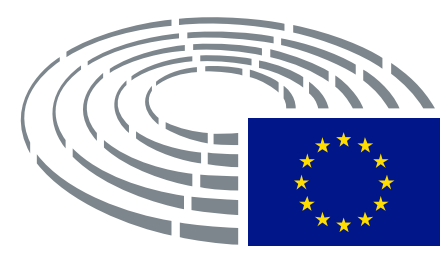

\title{
Precautionary Recapitalization: Time for a Review
}

\author{
External author: Martin Hellwig \\ Max Planck Institute, Bonn
}

\author{
Provided in advance of the public hearing \\ with the Chair of the Single Resolution Board in ECON \\ on 11 July 2017
}

\begin{abstract}
The first part of the paper considers the effects of pre-empting a resolution procedure for a troubled financial institution by a precautionary recapitalization as specified in Article 32 (4) (d) of the Bank Recovery and Resolution Directive (BRRD). Benefits are seen for the maintenance of systemically important operations of an institution with legally independent subsidiaries in multiple jurisdictions and possibly for the maintenance of lending in situations where an entire banking system is involved. Other systemic concerns, such as the maintenance of lending when only part of a banking system is affected, the avoidance of damage to money markets, and potential systemic effects from bailing in creditors, can be addressed in a resolution procedure under the rules of the BRRD and do not require the instrument of a precautionary recapitalization.
\end{abstract}

The second part of the paper provides a critical assessment of Article 32 (4) (d) of the BRRD and finds some weaknesses that contribute to raising taxpayers' costs or to reducing the effectiveness of the operation. The availability of precautionary recapitalization outside of resolution contributes to undue and costly delays in acknowledging and addressing problems. The conditions specified in the Directive are problematic, sometimes too tough, sometimes too lenient, most importantly because the objectives of State aid control differ from the objectives of the BRRD. The paper concludes with suggestions for reform. 
This paper was requested by the European Parliament's Economic and Monetary Affairs Committee.

\section{AUTHOR}

Martin Hellwig

Max Planck Institute for Research on Collective Goods

Bonn

\section{RESPONSIBLE ADMINISTRATOR}

\section{Benoit Mesnard}

Economic Governance Support Unit

Directorate for Economic and Scientific Policies

Directorate-General for the Internal Policies of the Union

European Parliament

B-1047 Brussels

\section{LANGUAGE VERSION}

\section{Original: EN}

\section{ABOUT THE EDITOR}

Economic Governance Support Unit provides in-house and external expertise to support EP committees and other parliamentary bodies in playing an effective role within the European Union framework for coordination and surveillance of economic and fiscal policies.

E-mail: egov@ep.europa.eu

This document is also available on Economic and Monetary Affairs Committee homepage at:

Manuscript completed in July 2017

(C) European Union, 2017

\section{DISCLAIMER}

The opinions expressed in this document are the sole responsibility of the authors and do not necessarily represent the official position of the European Parliament.

Reproduction and translation for non-commercial purposes are authorised, provided the source is acknowledged and the publisher is given prior notice and sent a copy. 


\section{CONTENTS}

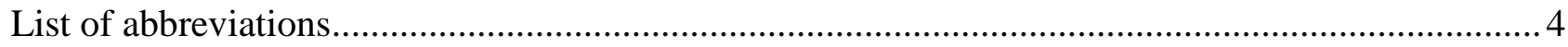

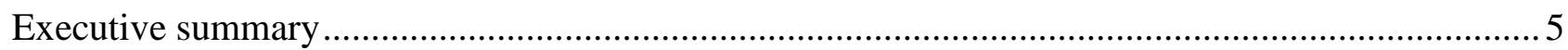

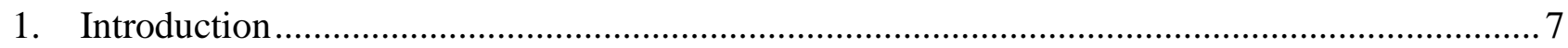

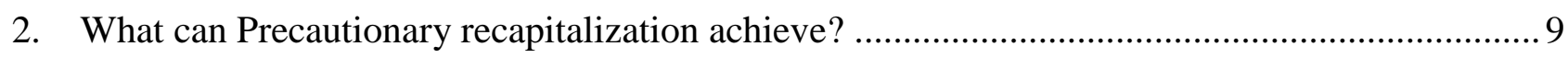

2.1 Maintenance of operations that matter for the financial system .................................. 10

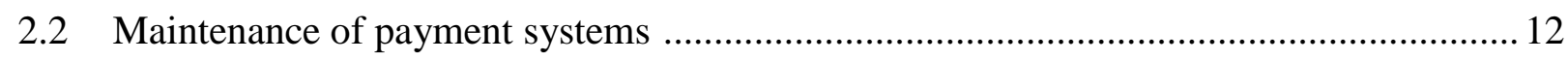

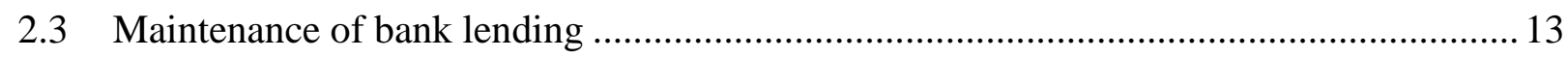

2.4 Impact on money market lenders and contagion in money markets ............................. 14

2.5 Impact on unsecured medium- and long-term lenders .......................................... 16

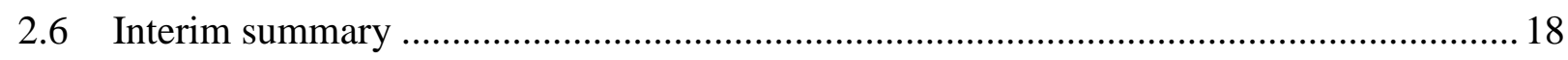

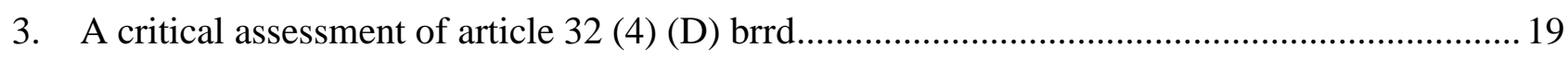

$\begin{array}{lll}3.1 & \text { Objectives, governance and procedure } & 19\end{array}$

3.2 The Conditions for a precautionary recapitalization .................................................. 21

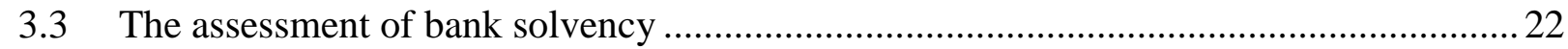

3.4 The role of the State aid framework .................................................................... 24

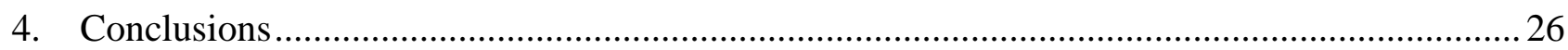

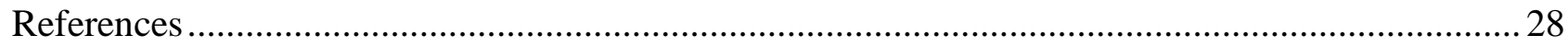




\section{LIST OF ABBREVIATIONS}

BRRD Bank Recovery and Resolution Directive

CJEU Court of Justice of the European Union

EBA European Banking Authority

ECB European Central Bank

FDIC Federal Deposit Insurance Corporation

GDP Gross Domestic Product

MPS Banca Monte dei Paschi di Siena

SRB Single Resolution Board

SRM Single Resolution Mechanism

SSM Single Supervisory Mechanism

TFEU Treaty on the Functioning of the European Union 


\section{EXECUTIVE SUMMARY}

The European Union's Bank Recovery and Resolution Directive (BRRD) of 2014 creates a special procedure for the resolution of financial institutions that are deemed to be failing or likely to fail. Under this procedure, the resolution authority takes control of the institution. Using the tools provided by the Directive, it addresses the problems of the institution while making sure that systemically important functions are maintained. In the process, the resolution authority may impose losses on shareholders and creditors, as one way to restore solvency, or to facilitate a sale of the bank. If the bail-in-able liabilities are insufficient or if a bail-in of certain creditors seems to entail significant systemic risk, the resolution authority can have recourse to public funds, but in a resolution procedure such recourse comes only after a specified threshold for the bail-in of shareholders and creditors has been reached.

This prioritization of bail-ins of investors over contributions of public funds can be circumvented through a precautionary recapitalization under Article 32 (4) (d) of the BRRD. Under this article, a Member State government can preempt a resolution procedure by injecting equity so as to cover a capital shortfall established by stress tests and/or asset quality reviews of the competent authorities. Precautionary recapitalizations must be compatible with the EU's State aid framework.

The paper first investigates whether there are any benefits to having the tool of precautionary recapitalization as well as the tools available in resolution. For financial institutions that have systemically important functions in multiple jurisdictions, the preemption of a resolution procedure by a precautionary recapitalization may be advantageous because in the absence of binding agreements on a single-point-of-entry resolution procedure, a resolution regime may involve different authorities of different jurisdictions each taking control of the legally independent units in their domains. In that case, certain integrated operations may no longer be viable, and it may be impossible to maintain systemically important functions in the different jurisdictions. In contrast, the maintenance of payment systems and maintenance of lending, which are also of systemically important, can be addressed in a resolution regime under the BRRD and do not necessarily warrant a precautionary recapitalization, at least if the resolution authority has the resources to maintain the bank's operations for a while, in particular the human resources needed to maintain and control lending. Concerns about the impact on bank lenders also do not warrant a precautionary recapitalization. To the extent that the lenders themselves pose systemic risks, the problem can be addressed through exemptions from bail-in under Articles 44 (2) and (3) BRRD. Beyond that, the argument that bail-in of unsecured senior creditors is likely to raise funding costs for all banks is highly problematic as it involves the implicit principle that it is desirable to have taxpayers participate in banks' losses in order to reduce the banks' funding costs. This principle is incompatible with the State aid framework of the EU because the reductions in funding costs that are due to an anticipation of bailouts distort competition in the Internal Market.

The second part of the paper provides a detailed critical assessment of Article 32 (4) (d) of the BRRD. Some major weaknesses are identified. First, whereas the procedure for State aid control provides a well-established routine for balancing the interests and desires of Member State government with the need to protect the Internal Market, the procedure itself takes time, and the delays involved contribute to magnifying losses and frictions. In actual cases, delays have allowed professional holders of subordinated debt to get out early and without suffering major losses; the replacement of these professionals by unsophisticated investors has contributed to making bail-ins very contentious politically. Second the conditions for recapitalizations that are listed in Article 32 (4) (d) BRRD are somewhat problematic. Some of them are too restrictive, at least for those cases where a precautionary recapitalization would be genuinely useful. Some of them seem mutually contradictory. Most importantly, the focus on solvency suffers from the fact that assessments of solvency involve significant subjective elements. In practice, the handling of these subjective elements by the authorities has contributed to delay and the resulting magnification of costs to taxpayers. Third, there 
is an inherent tension between the focus on competition in the Internal Market, which is the focus of State aid control, and the objectives of financial stability and containment of costs to taxpayers that underlie the BRRD.

The paper concludes with some suggestions for reform:

- Restrict the domain of precautionary recapitalization to those cases where a pre-emption of resolution makes a difference to financial stability or to the maintenance of bank lending.

- Within the Banking Union, move the entire procedure to the European level, involving the ESM as well as the SRB.

- Ensure that the SRB can mobilize the resources needed to ensure the maintenance of lending (as well as other systemically important functions) in resolution.

- Clarify the relation between the BRRD's objectives of preserving financial stability and reducing costs to taxpayers and the State aid framework's objective of avoiding distortions to competition.

- Give supervisory and resolution authorities incentives to avoid delays in recognizing solvency problems of banks. 


\section{INTRODUCTION}

At the peak of the financial crisis of 2007-09, financial institutions of many European countries were provided with support from their governments, through capital injections and through guarantees. In the panic that had followed the Lehman bankruptcy, the support was intended to restore confidence, to ensure the continued funding of financial institutions, and to stop the vicious circle of fire sales, asset price declines and solvency concerns.

Under normal circumstances, in a market economy, firms that have problems do not receive support from their governments. If they are unable to meet, or even to renegotiate, their obligations, they are subjected to legal procedures. In an insolvency or bankruptcy procedure, the responsible authorities take control over the firm's assets. The proceeds from disposing of the assets are distributed to creditors in accordance with their standing in the hierarchy of claims. If the proceeds fall short of the total amount owed, the owners' equity is wiped out, and the creditors participate in the losses, beginning with those who are lowest in the hierarchy.

In the financial crisis, governments departed from these principles. By injecting equity and providing guarantees, they had taxpayers participate in the absorption of losses. Indeed, taxpayers took the role of a loss absorber of the first resort, ahead even of the holders of subordinated and hybrid debt that had previously been issued with a view to participating in loss absorption and that had been treated as (Tier 2) equity for regulatory purposes.

In 2008, having the taxpayer stand in as a loss absorber of the first resort was motivated by fears of systemic repercussions from any triggering of procedures that would be needed to make creditors participate in the absorption of banks' losses. In the post-Lehman panic, it seemed as if any untoward news, no matter how substantial or insubstantial it might be, would contribute to the system meltdown and cause significant further damage. In fact, given the asset freezes associated with traditional insolvency procedures, such interventions would have substantial effects on the institutions' creditors. Moreover, any such intervention might make investors fearful of similar interventions at other institutions; this would endanger these other institutions' funding and might force them to engage in fire sales of assets. ${ }^{1}$

In contrast to the United States with their long tradition of having the deposit insurer take control and dispose of problem banks, European countries at the time dealt with problem banks under general insolvency law or under regulatory rules that followed the logic of insolvency law, with priority given to creditor protection and the preservation of assets, regardless of the systemic effects of, e.g., an asset freeze. ${ }^{2}$ In the post-Lehman crisis in 2008 , relying on such procedures seemed too dangerous.

Since then, the European Union has introduced important legal reforms for procedures to deal with problem banks. The Bank Recovery and Resolution Directive (BRRD) provides for a common set of rules and for institutional infrastructures at the level of Member States. For large banks in the euro area, the Single Resolution Mechanism (SRM) provides for a common institutional infrastructure. The BRRD is based on the principle that losses should be absorbed by owners and creditors in accordance with their standing in the hierarchy of claims, so taxpayers would not be involved at all. At most, if concerns for financial stability make some creditor bailouts unavoidable (in addition to the exceptions from bail-in that are listed in the BRRD itself), taxpayers should be involved as loss absorbers of the last resort (Art. 56).

\footnotetext{
${ }^{1}$ Geithner (2014) suggests that the bailing in of creditors at Washington Mutual had exactly this kind of effect.

${ }^{2}$ For example, the German Kreditwesengesetz (KWG) did allow for bank supervisors to step in and take control even in the absence of default or insolvency, but the priority given to creditor protection was held to imply that the intervention had to follow similar principles as insolvency proceedings. See Hellwig (2012).
} 
However, the BRRD contains an exception to these principles. Art. 32 (4) (d) provides for the possibility of a "precautionary recapitalization", where a Member State government injects capital or provides guarantees to a bank "in order to remedy a serious disturbance in the economy ... and preserve financial stability". The support is subject to various conditions and must be approved under the EU's State aid framework,

The Commission's original proposal for the BRRD had contained a provision for government guarantees, for purposes of financial stability, with a time limit of three months. In the course of the legislation, the Council added the purpose of remedying a serious disturbance in the economy, as well as the possibility of injecting capital, and removed the three-month time limit for the measure. Whereas the Commission's original proposal was narrowly designed to address certain financialstability concerns, especially concerns related to breakdowns of liquidity in the financial system, the final legislation had a much wider scope, in terms of rationale, instruments allowed and time length allowed.

Since the BRRD came into effect in January 2015, there have been five cases involving precautionary recapitalizations. In late 2015, the Commission granted precautionary recapitalizations of Piraeus Bank and National Bank of Greece. More recently, Italy proposed precautionary recapitalizations for Monte dei Paschi di Siena, Banca Populare di Vicenza, and Veneto Banca. For Monte dei Paschi di Siena (MPS), the proposal was accepted, for the other two banks, the conditions imposed to ensure compatibility with the EU's State aid framework were not fulfilled, and the banks are being liquidated under Italian law, in accordance with Article 18 (8) of the SRM Regulation.

In contrast, the SRM has only been called upon once. In June 2017, Banco Popular Español went into resolution and, after a write-down of equity and subordinated debt, was sold to Banco Santander, which proposed to raise new equity for the purpose.

Given these experiences, it seems appropriate to review the role of this instrument, its purposes, the conditions under which it can be used, and the procedures that are involved. 


\section{WHAT CAN PRECAUTIONARY RECAPITALIZATION ACHIEVE?}

I begin by examining why a precautionary recapitalization might be useful. The answer to this question depends on what the alternatives are considered to be. Given the context of Article 32 BRRD, I take the alternative to be an action of the resolution authority, usually the initiation of a resolution procedure. Article 32 (4) (d) BRRD states the principle that a need for extraordinary public support is a sufficient reason for triggering resolution and then goes on to make an exception for precautionary recapitalization.

If a bank's recourse to extraordinary public support were to trigger a resolution procedure, control would shift from the bank's managers and owners to the resolution authority and, possibly, the authorities in charge of insolvency law. The resolution authority would initiate the valuation and bailin procedures stipulated by the Directive. Any public support would be at the discretion of the resolution authorities. Moreover, before such support can be called upon, equity and bail-in-able debt amounting to at least $8 \%$ of total assets must have been bailed in.

A precautionary recapitalization under Article 32 (4) (d) BRRD differs from this procedure in two major respects:

- There is no shift of control to the resolution authority.

- The Directive does not make bail-in of creditors a precondition of the injection of public funds The question is why these effects matter and how they relate to the professed objectives of remedying a serious disturbance in the economy and preserving financial stability.

In answering these questions, I distinguish between effects on the bank's operations and effects on investors. The change in control that comes with resolution affects the bank's ability to maintain operations that are relevant for the functioning of the financial system, as well as operations by which the bank serves the real economy. The bailing in of investors has direct effects in the form of losses to these investors, as well as indirect effects, from the investors' reactions to these losses or from third-party reactions to the events. I will discuss each of these effects in turn.

Before embarking on the analysis, I note that, with respect to both effects, the difference between a precautionary recapitalization and a resolution action may not be as stark as the above statement suggests. First, Article 59 BRRD allows for the possibility that the resolution authority might impose a bail-in of investors without actually initiating a resolution procedure. In such a case, the action of the resolution authority need not involve a shift of control. Second, under prevailing procedures of State aid control, approval of a precautionary recapitalization requires some private sector participation, which may take the form new equity funding from private investors and/or a bailing in of shareholders and debt holders. ${ }^{3}$

Even so, the differences are there. With respect to control, the decision on whether to rely on a bailin under Article 59 BRRD or to initiate resolution rests with the resolution authority. Article 59 (3)

(e) extends the Member State's right to preempt the authority's action to this constellation.

With respect to bail-in of creditors, under current law and current practice, senior unsecured lenders are not bailed in when there is a precautionary recapitalization but they may be bailed in when the banks is submitted to a resolution procedure, or when the resolution authority takes an action under Article 59 BRRD. The Court of Justice of the European Union (CJEU) has clarified that a bail-in of subordinated lenders and shareholders can be imposed in connection with a precautionary recapitalization, as well as a resolution action. However, in a precautionary recapitalization, the Commission cannot impose bail-in as a matter of course but, if the Member State raises the issue, the

\footnotetext{
${ }^{3}$ See the European Commission's Banking Communication of 2013.
} 
Commission must examine whether there might not be reasons to forego the burden sharing by private investors or to have it take a form other than a bail-in. ${ }^{4}$ For subordinated debt and equity, therefore, as for senior unsecured debt, the extent of burden sharing is also likely to be smaller in a recapitalization than in the resolution regime, but the difference is smaller. ${ }^{5}$ Thus, in a precautionary recapitalization, taxpayers are not quite the loss absorbers of the first resort, but they are exposed to losses ahead of unsecured senior debt holders, and perhaps cases even the subordinated debt holders.

The argument given by the CJEU suggests that it might not be legal to also bail in senior unsecured creditors in a precautionary recapitalization. The Court does not discuss the issue, but the argument it gives for subordinated debt stresses the equity-like features of this debt, arguing that, in return for having accepted to bear additional risks, investors have obtained higher contractual interest rates and therefore must have had some expectation that, if the bank got into difficulties, they would be called upon to absorb losses. The Court's focus on the difference between subordinated debt and senior debt suggests that the Court considers the senior debt holders' claims to be not only stronger, but also immune to any interference outside of established procedures (resolution or insolvency) for dealing with a bank's actual or anticipated inability to meet its commitments.

\subsection{Maintenance of operations that matter for the financial system}

When Lehman Brothers went into bankruptcy, an important systemic effect was due to the disappearance of Lehman Brothers as a market maker for derivatives, in particular credit default swaps. Market participants who had counted on using contracts with Lehman Brothers to hedge their risks and/or to reduce the equity needed to back their assets found that they could not do so, especially since other market makers were unable or unwilling to step in immediately. The disappearance of hedging opportunities caused these market participants to adjust their plans, including by shedding assets whose risks they could no longer hedge. Such reactions contributed to the downward pressure on prices.

In contrast to traditional insolvency law, which focuses primarily on creditor protection, Article 31 BRRD names maintaining the continuity of financial functions as the first resolution objective. As a matter of principle, therefore, one might suppose that, in a resolution procedure under the BRRD, systemically important operations such as market making would be maintained. The operations of central clearing houses, which have become prominent under post-crisis regulation, must also be mentioned here.

In practice, however, there is a snag. Some of the institutions that provide systemically important financial services are active in multiple jurisdictions. Under prevailing law, resolution would involve multiple points of entry, i.e. each legally independent subsidiary would be resolved by the authorities of the country in which it is located. With entries by different authorities in different jurisdictions, the control shifts that go along with resolution would destroy the viability of operations that have been carried out in an integrated manner across subsidiaries. As a result, the ability to maintain systemically important operations in any one jurisdiction may suffer. ${ }^{6}$

Lehman Brothers had integrated cash management. At the close of business in London, cash reserves would go from there to New York, at the close of business in New York from there to Asia, and eventually back to London. When the UK authorities entered the bank after it went into bankruptcy, there was no cash because the cash that had been sent to New York at the close of the preceding

\footnotetext{
${ }^{4}$ See the judgment of the Court of Justice of the European Union of 19 July 2016 in the Case C-526/14, Tadej Kotnik and others versus Državni zbor Republike Slovenje.

${ }^{5}$ As indicated by the case of MPS, in a precautionary recapitalization, there is also the possibility of mitigating some of the losses of subordinated debt holders through compensation payments from the government.

${ }^{6}$ For a detailed discussion, see ASC 2010), Hellwig (2014).
}

PE 602.089 
business day had not come back. Even if they had wanted to do so, they were therefore unable to maintain Lehman's market making operations in London - unless they put in public money. Integrated IT systems may pose even bigger problems.

International bodies like the Financial Stability Board have proposed a single-point-of-entry approach to resolution, and many globally operating banks have put the single-point-of-entry approach into their "living wills", i.e. their resolution plans. However, this is not (yet?) the law and, even if it was, I would see a high probability that some jurisdictions would not abide by it. The issues that arise in resolution are so highly political that I cannot see, for example, the United States accepting for Deutsche Bank or BNP Paribas to be resolved by the Single Resolution Mechanism, without their having any say. In this respect, the ring-fencing measures that the US authorities have imposed on foreign banks over the past few years speak for themselves, as do their continued refusals to accept the banks' recovery and resolution plans.

Proponents of a single-point-of-entry resolution regime often suggest that the issues of distribution of losses across jurisdictions can be handled by a suitable arrangement of internal TLAC, i.e. bail-inable intra-institution debt instruments that can be used to allocate losses between the parent and its subsidiaries. The argument would be convincing if the acknowledgment of losses and the allocation of these losses, within the corporation and in relations to outside investors were sufficient to overcome the crisis. In this case, a resolution authority in the EU might even use the powers it has been given under Article 59 BRRD to implement the needed bail-ins without initiating a resolution procedure and taking control.

However, if the amount of bail-in-able debt is insufficient, there is more to resolution than merely bail-in. The word "insufficient" here refers not to losses and loss absorption needs as determined by the authorities but to loss absorption needs conjectured by investors. In certain situations, and especially if the bank and its supervisors have been slow to recognize losses, investors will be suspicious of whether sufficient write-downs have been taken. Perhaps write-downs have been kept artificially low in order to make sure that they are covered by the available bail-in-able debt... If such suspicions prevail in the market, the bank will not be able to attract new equity funding and perhaps not even new subordinated debt funding. If investors are suspicious about the scale of losses that are yet to be expected and they are concerned about the credibility of deposit insurance and the Directive's exceptions from bail-in, or about the values of posted collaterals, they may even withdraw deposits and other short-term debt funding of the bank. In such situations, either a credibly large injection of funds or an initiation of resolution may be necessary to stabilize the bank.

Lehman Brothers provides a case in point. Throughout the summer of 2008, doubts had been raised about the bank's solvency. In response to this discussion, the bank had actually raised what seemed like a sizeable amount of additional equity. However, market investors had less and less confidence in the valuations given to mortgages that Lehman Brothers held in warehousing. The lack of confidence induced the repo lenders to withdraw their funding. When JPMorganChase as the thirdparty agent in Lehman Brothers' tri-party repo borrowing asked for more collateral, the bank could not comply and became unable to meet its payment obligations. Subsequently, in the bankruptcy procedure, the bank's losses were found to be much larger than anticipated. Even allowing for the fact that the losses were exacerbated by subsequent developments, it seems unlikely that a simple bail-in exercise would have been sufficient to stabilize investor confidence and market funding of the bank.

However, if control shifts to the resolution authorities, the main political issue concerns the maintenance of operations, rather than the allocation of losses. With a centralization of funding at an institution like Deutsche Bank, a single-point-of-entry resolution regime would require US authorities to trust European authorities to continue funding systemically important operations in the United States, even though these operations are risky and losses from these operations will aggravate the 
problems. A single-point-of-entry resolution regime would also require the authorities in Norway to trust the Swedish authorities to allow Nordea to maintain its lending in Norway. The Single Resolution Mechanism addresses these conflicts for a large part of the European Union. However, for financial institutions with systemically important operations in the United States and the United Kingdom, as well as the euro area, the problem is unsolved.

For globally systemically important financial institutions, I therefore believe that the exception provided by Article 32 (4) (d) BRRD is important as it provides a basis for avoiding systemic risks that would be associated with the breakdown of systemically important operations under a resolution regime where control is not just shifted away from managers and owners, but control is in fact split between the resolution authorities of different countries. However, none of the banks for which precautionary recapitalizations have been provided or applied for belong to this category.

\subsection{Maintenance of payment systems}

In the relation between banks and the real economy, the payment system is particularly important. Banks provide their customers with access to the payment system. Depositors rely on their bank accounts for non-cash transactions. In the Great Depression of the 1930s, the breakdown of payments mechanisms through bank failures and bank "holidays" had very negative effects on the real economy. ${ }^{7}$

Relative to that time, however, concerns about access to deposits and about the ability to use deposits for payments have been much reduced. Customers whose deposits are protected by deposit insurance should be completely unaffected by the entry of their bank into a resolution regime; thus in the United States, customers hardly even notice the Federal Deposit Insurance Corporation's taking control of their bank. (In some European countries perhaps deposit insurance is not quite as firmly established, but then it would be important to improve on the enforcement of the Deposit Guarantee Schemes Directive.)

Similarly, entry of a bank into a resolution regime should not have significant effects on the bank's ability to participate in inter-bank payments systems. To the extent that such systems involve settlement in real time, without e.g. intra-day credit, counterparty trust plays no role anyway. Even where elements of credit are involved, the exemption of such very-short-term credit from any sort of bail-in should ensure the bank's ability to participate in such systems.

In the fall of 2008, certain international interbank payment systems were much affected by the crisis. In particular, the system of using letters of credit to support payments for large transactions in international trade, substituting trust in banks and between banks for trust between exporters and importers, was damaged by the implosion of trust in the financial system. The resulting deterioration of the international payment system seems to have contributed to the sharp fall in world trade at that time.

However, whereas it is important to avoid a repetition of this experience, this consideration does not provide much of a reason to avoid the shift in control that is associated with the bank's entry into a resolution regime and instead engage in a precautionary recapitalization. After all, the resolution authority has the task of maintaining systemically important functions. Moreover, the bank's participation in the payment systems is unlikely to be much affected by the fragmentation of control under multiple-point-of-entry resolution. To the extent that such systems involve credit, and trust between banks and the statutory exemptions from bail-in under Article 44 (2) BRRD do not apply, it would be natural for the resolution authority to use the authority granted under Article 44 (3) BRRD to extend such an exemption as needed to maintain the bank's participation in payment systems.

${ }^{7}$ Friedman and Schwartz (1963), Born (1967).

PE 602.089 
In summary, I do not believe that the maintenance of a bank's participation in payment systems necessitates the flexibility provided by the exception in Article 32 (4) (d) BRRD.

\subsection{Maintenance of bank lending}

Bank lending is also essential for the real economy, in particular lending to small and medium enterprises and to lending to individuals, who usually do not have access to outside funding from other sources. Breakdowns in bank lending are often considered to be a major reason why recessions that are accompanied by financial crises tend to be much worse than "normal" recessions, in which the financial system is unaffected. Thus, Bernanke (1983) suggested that, in the United States, the Great Depression was much exacerbated because the banking crises disrupted traditional lending channels and depressed investment. ${ }^{8}$ In his account, the closure of banks destroys the information capital that these banks have accumulated, i.e. their understanding of actual and potential loan applicants and their ability to distinguish between good risks and bad risks. Because other institutions lack this information, they are unwilling to step in, overall lending is reduced, and investment suffers.

Like the above concerns about the payments system, however, concerns about lending do not necessarily warrant the conclusion that a precautionary recapitalization is preferable to an entry into a resolution regime. The following considerations must be taken into account. First, many firms, even those of moderate size, go out of their way to cultivate multiple banking relationships. They do so as a way of protecting themselves against the possibility that a single "main bank" might abuse the power it has in order to extract monopoly rents from the firm. Multiple banking relations provide a basis for ensuring that no one bank has a large information advantage that might provide it with monopoly power. The withdrawal of one bank therefore need not imply that the firm is cut off from bank lending altogether. The firm may simply move its borrowing to one of the other banks that have sufficient information about it. ${ }^{9}$

Second, if the resolution authority sells all or part of the bank's business to another bank under Articles 38, 39 BRRD, the information capital that the problem bank has accumulated remains operative. For example, one may presume that Banco Santander will be able to make use of the information that Banco Popular Español had about its customers because the loan officers involved will continue to be around, at least for a while. Similarly, in the crisis of regional and cantonal banks in Switzerland in the early 1990s, all but one of the banks which had problems were taken over by the Big Banks, without any decline in lending to small and medium enterprises other than that which was to be expected anyway after the lending bubble of the late 1980s.

Third, even if an entire banking system is affected, so that the shift to borrowing from another bank may not be possible, some continuation of lending will take place under the responsibility of the resolution authority itself. Thus in the Swedish crisis of the early 1990s, the authorities did take control and did provide for a continuation of banking services, including lending, in the words of Stefan Ingves at the 2015 ECB Forum on Banking Supervision, the government acted "as the banker of last resort".

The real issue here is whether the resolution authority has the resources to maintain such banking services when an entire banking system is involved. At an operational level, presumably the authority can call on the bank employees who were doing the job before, but if an entire banking system is

\footnotetext{
${ }^{8}$ See also Bernanke (1995). Born's (1967) account of the effects of the German banking crisis of 1931 also emphasizes the drastic downturn in bank lending.

${ }^{9}$ For empirical accounts in the context of German bank-firm relations, see Edwards and Fischer (1994) and Harhoff and Körting (1998). The importance of rent extraction is emphasized in the analysis of Japanese "main bank" relations by Weinstein and Yafeh (1997).
} 
involved, the authority may not have enough people to control the operations as it should. For example, in the savings and loans crisis in the United States, in the early 1990s, the Federal Deposit Insurance Corporation had to call on people who were already in retirement in order to cope with the large number of affected institutions. ${ }^{10}$

Fourth, not all bank lending is economically desirable, and the quality of bank lending may actually be improved if a bank that is in trouble is taken into a resolution regime. For an example, consider the Japanese banking crisis of the 1990s. In that crisis, the authorities chose to exercise forbearance, allowing major banks to carry on without intervention even though the solvency of these banks was doubtful. These banks in turn exercised forbearance towards their own borrowers including many whose solvency was questionable. Continued lending to these customers was a way of rolling over loans and avoiding defaults, which would have required write-downs in the banks' books and would have put the banks' own solvency at stake.

The forbearance contributed to the delay in the cleanup of the Japanese banking crisis. It also contributed to the 1990s' slowdown of productivity growth in Japan. Because bank lending focused on keeping incumbent borrowers out of default, new firms with new ideas found it more difficult to obtain funding, partly because the requisite funds went to incumbents and partly because it seemed unattractive to undertake or to fund ventures that would enter into competition with incumbents known to have financiers with deep pockets. ${ }^{11}$

\subsection{Impact on money market lenders and contagion in money markets}

Among the many damaging effects of the Lehman bankruptcy, the most detrimental was probably due to the loss of some US\$ 800 million that was suffered by the Reserve Primary money market mutual fund. The loss caused Reserve Primary to "break the buck", i.e. to have the value of a share go below one dollar. When this was announced, investors began to run on Reserve Primary so that, in a matter of days, some US $\$ 60$ billion (out of 62 billion) had been withdrawn. Other money market mutual funds that were known to have followed similar investment strategies were also run upon. The erosion of their funding caused the money market mutual funds in turn to withdraw their funding from other institutions, in particular banks. US investment banks, which were suspected of having run similar risks as Lehman Brothers, were hit hardest. Much damage was also done to European covered-bond banks (Dexia, Hypo Real Estate), which had relied on the money market to fund the excess coverage for their covered bond, i.e., the amounts by which their portfolios of mortgages and public debt that served as collaterals exceeded the nominal values of their covered bonds. ${ }^{12}$

The freeze of money markets caused banks to scramble for cash, in particular, by liquidating assets, which in turn put downward pressure on asset prices. The price declines in turn deepened the panic and reinforced concerns about banks' solvency.

The episode indicates that it is important to insulate money markets and the system of liquidity management and liquidity provision from the effects of bank failures. This concern is similar to the concerns that led to the introduction of deposit insurance in the past. With both concerns, the problem is that banks rely a lot on short-term funding and are therefore vulnerable to being run upon. With deposits, the problem is solved by having a deposit insurance system that is credible and that eliminates depositors' worries about the safety and accessibility of the funds they put into the bank (but even then, some concerns remain for large deposits that go above the limits for deposit insurance). With money market funding, the problem is somewhat more complicated because this

\footnotetext{
${ }^{10}$ Curry and Shibut (2000).

${ }^{11}$ See Hoshi and Kashyap (2004). A few years ago, the CEO of Maersk complained that the same mechanism was distorting competition in international shipping.

${ }^{12}$ For a more detailed account, see Financial Crisis Inquiry Commission (2011), Admati and Hellwig (2013), Ch. 5.

PE 602.089 
funding depends not only on the willingness of, e.g., money market funds to lend to the bank but also on the willingness of investors to stay with the money market fund.

Under the BRRD, money market lenders to banks are protected by the exemption from bail-in that Article 42 (2) BRRD grants for very short-term lending and for collateralized lending. The typical repo loan would be covered by one or the other of these exemptions. The BRRD thus protects money market lenders from the kind of loss that Reserve Primary suffered in the Lehman bankruptcy and that triggered the run on Reserve Primary and the other money market funds.

Investors in money market funds might still be motivated to withdraw their funds, e.g., because they fear that the exemptions in Article 42 (2) BRRD might not be sustainable. But then such fears might cause them to run regardless of whether the bank is put into a resolution regime. Such a run on money market funds lending to a problem bank might even be triggered by a precautionary recapitalization.

A precautionary recapitalization under Article 32 (4) (d) BRRD ensures that the bank satisfies regulatory requirements even in the adverse scenarios of the supervisors' stress tests, but that may not be enough to reassure investors that the bank is actually solvent, or that it is able to withstand losses over the next few months. Stress tests have been criticized for not being severe enough, even in the adverse scenarios, because asset valuations are often too optimistic and certain risks are not taken into account. ${ }^{13}$ There have been too many cases where banks that had been declared solvent and even well-capitalized after a stress test got into trouble just a few months later, from problems that were already present at the time of the stress test. ${ }^{14}$

If investors are suspicious whether a precautionary recapitalization that is limited by the BRRD's requirement of proportionality will be sufficient to restore the bank's health, they may withdraw or threaten to withdraw their funding from money market institutions that lend to this bank; the money market institutions in turn will then withdraw their lending, either to forestall the erosion of their funding or because the erosion of their funding leaves them no other choice. These forces could be seen at work in the dollar funding of European banks in the summer of 2011. Despite the bill of health that was provided by the European Banking Authority's stress test, investors were skeptical about the banks' ability to withstand the consequences of the upcoming haircut on Greek sovereign debt. The dollar funding of European banks came under pressure, which necessitated large central-bank interventions, the ECB using the swap agreement with the US Federal Reserve to provide dollar liquidity to European institutions. One should also recall that Monte dei Paschi di Siena, Banca Popolare di Vicenza and Veneto Banca all have had recapitalizations in the recent past, the latter two as late as 2016, and that these recapitalizations provided no more than a temporary respite.

In summary, given the exemptions from bail-in in the BRRD, I do not see fragility of money market funding as a matter in which a precautionary recapitalization has significant advantages over resolution. Whether short-term funding is more robust after a precautionary recapitalization or in a resolution regime depends on circumstances. Given the collective-choice aspects involved in investors' running on a money market fund (or on a bank), I suspect that such contingencies do not lend themselves to codification, i.e., it would be futile to have a legal norm indicating under what conditions concerns about money market lending should or should not lead to a preference for precautionary recapitalizations.

\footnotetext{
${ }^{13}$ For example, in the 2014 Comprehensive Assessment, the assumption that funding structures would remain unchanged meant that, for banks which got their short-term funding from the ECB, the "adverse" interest rate shock actually was beneficial as the presumed rise in the interest rate was taken to affect only the costs of market funding, not the cost of ECB funding, and moreover on the assets side of the balance sheet, higher interest rates meant higher returns from new lending, while adverse valuation effects did not matter much because loans and government bonds were held at nominal values in the bank book.

${ }^{14}$ Irish banks in 2010, Dexia in 2011, Greek banks in 2015.
} 
If I add the consideration that liquidity can also be provided by the central bank, I come to the conclusion that concerns about money market borrowing and lending should actually induce a preference for resolution and against a precautionary recapitalization. Having the central bank as a liquidity backstop neutralizes the damage from the breakdown of money market borrowing and lending in either constellation. However the change of governance under a resolution procedure reduces the scope for moral hazard, i.e., the possibility that the bank, its owners, and its managers might abuse the availability of funding from the central bank in order to delay corrective actions that are needed.

\subsection{Impact on unsecured medium- and long-term lenders}

To conclude this discussion, I consider the effects on medium- and long-term lenders of having a precautionary recapitalization rather than a resolution of the bank. As mentioned above, under current law and current practice, senior unsecured lenders are not bailed in when there is a precautionary recapitalization but they may be bailed in when the banks is submitted to a resolution procedure. Moreover, in a precautionary recapitalization, a bail-in of subordinated lenders and shareholders cannot be imposed as a matter of course but the Commission must examine in detail whether the burden sharing might take a form other than a bail-in or might not be foregone altogether. ${ }^{15}$ For subordinated debt and equity, therefore, as for senior unsecured debt, the extent of burden sharing can be smaller in a recapitalization than in resolution.

The question is how to assess these differences between burden sharing in a precautionary recapitalization and burden sharing in resolution. Three effects seem relevant: first, the immediate impact of the losses imposed on the debt holders; second, the impact on the bank's funding; third, the impact on the cost to banks of funding with such debt.

Losses are always painful to bear. However, in an economic system in which people are free to choose their investments as they like, they are also responsible for the consequences of their decisions, i.e. investors in bank debt of any kind must be prepared to bear losses. The BRRD's exemptions from bail-in for depositors and for very short-term lenders violate this principle, but as I explained above, the violation is needed to limit the systemic impact of bank defaults or fears of bank default on payment systems and systems for liquidity provision. With medium- or long-term debt, such systemic concerns can also arise if the debt holders are themselves financial institutions, for example insurance companies or other banks. The Liikanen Report, which had introduced the notion of bail-in-able debt, had also called for rules ensuring that the holders would be able to bear the losses, e.g., a 100\% backing by equity if the holder was a bank. However, the rules that we actually have leave a lot of room for losses on bail-in-able debt to have negative systemic effects.

However, this concern does not justify the reductions of burden sharing that can be expected when a bank is given a precautionary recapitalization. The bank is likely to have investors that are systemically unimportant as well as investors that are systemically important. In the case of the German bank Hypo Real Estate, for instance, the debt holders that were bailed out consisted not only of the likes of Deutsche Bank and Allianz, but also of non-financial institutions such as the organized churches, public television corporations, municipalities, and pension institutions. By far the larger part of the unsecured funding came from the latter. With a view to saving taxpayer money, it therefore seems appropriate to deal with specific systemic effects by means of discretionary exemptions under Article 44 (3) BRRD, instead of bailing all debt holders out merely because the impact of a bail-in on some debt holders might have adverse systemic consequences.

Threats to bank funding are not much of an issue in this context. By its very nature, medium- and long-term debt does not have to be constantly renewed. If a bail-in of unsecured debt forecloses the

${ }^{15}$ See the judgment of the Court of Justice of the European Union of 19 July 2016 in the Case C-526/14, Tadej Kotnik and others versus Državni zbor Republike Slovenje.

PE 602.089 
bank's access to such funding, the immediate impact on the bank's funding needs is therefore relatively small. As the debt matures, new funding needs arise, but this process will take place over time, without a panic.

We have actually seen such processes in the Italian developments. Around 2015, institutional investors in subordinated debt of Banca Popolare di Vicenza and Veneto Banca withdrew their funding. They were replaced by retail customers, private households and non-financial companies, to some extent also by the ECB's providing funding to these banks. The ease with which this substitution occurred must be a cause for concern, for the replacement of institutional investors by retail investors raises questions about consumer protection. With Monte dei Paschi di Siena, the same kind of replacement also took place, albeit somewhat earlier, and involved significant mis-selling of subordinated debt to people who were not professionals. Such selling of risky debt to nonprofessionals after the professionals have got out contributes to a political atmosphere in which bailin is considered illegitimate and that these investors should be compensated. One may suppose that the costs to taxpayers of the MPS bailout would have been significantly smaller if the bank had been put into resolution and shareholders and unsecured debt holders had been bailed in as of 2012. The delay since then, which was facilitated by the recapitalization in 2013 , has magnified the cost to taxpayers. In the case of the two Venetian banks, the costs of delay have been similarly significant, and the recapitalization of 2016 was a complete waste. ${ }^{16}$

Finally I consider the impact of burden sharing on banks' funding costs. The Italian government seems to fear that a bail-in of senior unsecured debt creates systemic risk because, when investors realize that they can be bailed in, they will be more reluctant to buy such debt, and bank funding by such debt will become more expensive.

If this fear were accepted as a reason for desisting from a bail-in of senior unsecured creditors, we would in fact be saying that banks should be entitled to fund at the low costs that are available if taxpayers guarantee their debt. The increase in funding costs that takes place if investors must reckon with the possibility of a bail-in is nothing more than a reflection of the fact that, without such a possibility, the losses would be borne by taxpayers. The mechanism has been amply discussed in the context of government guarantees for public banks, such as the German Landesbanken. In the context of that discussion, the principle has been established that, as they reduce a bank's funding costs by transferring risks to taxpayers, government guarantees distort competition in the Common Market and are incompatible with the EU's State aid framework. The only difference between that discussion and the argument now is that the earlier discussion concerned legally binding guarantees whereas the argument now concerns a form of government behavior, namely a precautionary recapitalization preempting burden sharing by senior unsecured debt, which affects funding costs by creating expectations about the government's future behavior even though no legally binding promise is given. The lack of a legally binding promise may reduce the strength of the effect, but otherwise the mechanism is the same, and so should be the assessment of its compatibility with the EU's State aid framework.

To be sure, in 2008, government recapitalizations and guarantees were standard instruments in fighting the financial crisis. However, the argument that is at stake here has little to do with those measures. As I mentioned in the introduction, in 2008 and 2009, precautionary recapitalizations and guarantees were given because most countries did not have special regimes for the resolution of banks in difficulties, and they were afraid that the application of standard insolvency law or bankruptcy law would exacerbate the crisis. Thus the criticism that was raised against the bail-in of unsecured debt holders of Washington Mutual focused on the damage that the bail-in would do to the institutions holding such debt and the systemic repercussions of that damage. ${ }^{17}$ This was not about burden sharing

\footnotetext{
${ }^{16}$ While the Atlante Fund, which provided the $€ 3.9$ billion for the recapitalization, is a private institution, the banks that put up the funds did so under government pressure, and the losses may come back to haunt them.

${ }^{17}$ See Geithner (2014).
} 
raising banks' funding costs but about burden sharing increasing doubts about some institutions' solvency, inducing a run of short-term lenders and forcing these institutions to take defensive actions that further contributed to the market downturn. I have discussed all these effects above and indicated that the BRRD provides ample means for dealing with them.

\subsection{Interim summary}

The conclusions of the analysis can briefly be summarized as follows. First, for financial institutions that have systemically important functions in multiple jurisdictions, a precautionary recapitalization has a major advantage over resolution because in the absence of binding agreements on a singlepoint-of-entry resolution procedure it may be impossible to maintain systemically important functions as the entry of different authorities in different jurisdictions may destroy basic operations that are integrated across the different parts of the organization. Second, maintenance of payment systems and maintenance of lending are also of great importance, but, at least, if the resolution authority has the resources to maintain the bank's operations for a while, in particular the human resources needed to maintain and control lending, these concerns can be addressed in a resolution regime under the BRRD and do not necessarily warrant a precautionary recapitalization. Third, concerns about the impact on bank lenders also do not warrant a precautionary recapitalization. To the extent that the lenders themselves pose systemic risks, the problem can be addressed through exemptions from bailin under Articles 44 (2) and (3) BRRD. Beyond that, the argument that bail-in of unsecured senior creditors is likely to raise funding costs for all banks is highly problematic as it involves the implicit principle that it is desirable to have taxpayers participate in banks' losses in order to reduce the banks' funding costs. This principle is incompatible with the State aid framework of the EU because the reductions in funding costs that are due to an anticipation of bailouts distort competition in the Internal Market. 


\section{A CRITICAL ASSESSMENT OF ARTICLE 32 (4) (D) BRRD}

In the second part of this review, I provide a critical assessment of the legal norm allowing precautionary recapitalizations, Article 32 (4) (d) BRRD. I do so in the light of the preceding considerations and in the light of the experience that we have had so far. I begin with the objectives of a precautionary recapitalization.

\subsection{Objectives, governance and procedure}

In the words of Article 32 (4) (d) BRRD, the objective of a precautionary recapitalization is to "remedy a serious disturbance to the economy ... and to preserve financial stability". As mentioned in the introduction, the first part of this objective was inserted by the Council in the process of legislation. The Commission's original proposal only referred to financial stability.

The formulation "remedy a serious disturbance to the economy" is very general and vague. Much depends on who is in charge of interpreting it. The issue is known from the application of Article 107 TFEU, the article dealing with State aid, from where the formulation is taken. In practice, the power to define the need to remedy a serious disturbance to the economy rests with the Member State government that wants to provide the State aid. This power is however constrained by the Commission's power to impose conditions ensuring that the aid does not distort competition in the Internal Market. Except for special cases, the Commission is not in a good position to challenge the asserted need to remedy a serious economic disturbance, but the conditions it imposes can be so restrictive that the result of the procedure is unattractive to Member State governments. The Commission's position is somewhat stronger in cases where the very purpose of the Member State government is in the distortion of competition, but the long dispute about government guarantees for public banks, in particular the German Landesbanken, shows that even then the imposition of competition rules may be a difficult task for the Commission.

In the present context, the issue of interpretation is exemplified by the cases of Banca Popolare di Vicenza and Veneto Banca. In applying for a precautionary recapitalization of these banks, the Italian government referred to the importance of these banks in the Veneto region, presumably with a view to maintaining lending to the real economy as discussed in Section 2.3 above. Given that these banks' market shares were on the order of ten percent in the region, two to three percent nationally, the claim was questionable. From what I understand, however, the Commission did not challenge this claim but asked for private-sector participation in the recapitalization. When this could not be obtained and the ECB declared the banks as failing or being about to fail, the SRB, presumably at the initiative of the Italian government, declared that a maintenance of these banks was not in the public interest and left them to be liquidated under Italian law. As part of the liquidation procedure, the "good" parts of the banks have been sold to Intesa Sanpaolo, which presumably will maintain the banks' lending in the Veneto region, quite in line with the arguments in Section 2.3 above.

The contrast between the initial assertion of a need for a precautionary recapitalization in order to remedy a serious economic disturbance and the later assertion that a resolution was not in the public interest is remarkable. The only feature that is common to the arguments given for a precautionary recapitalization and the arguments given for liquidation under Italian law is in the desire to keep the banks out of resolution, i.e., to avoid a shift of control to the Single Resolution Board and the bail-in of senior unsecured creditors in resolution.

There is of course no reason why the elected government of a sovereign state should be consistent in its arguments as it pursues its perceived political interests. Sovereignty includes the right to be inconsistent. In the area of banking, however, there are reasons for imposing limits on Member States' assertions of sovereignty, at least inside the Monetary Union. Whatever one Member State does in this area has implications for the Monetary Union as a whole that go beyond concerns about 
distortions of competition. One aspect concerns monetary policy. Banks play a key role in the transmission of monetary policy. If banks are unhealthy, the transmission mechanism is likely to be impaired, and the effectiveness of monetary policy may suffer. Another aspect concerns the possibility that bailouts of banks by governments may strain the fiscal capacity of the Member State, requiring it to apply for support from the European Stability Mechanism, as happened in the Irish and Spanish crises in 2010 and 2012. In 2012, these concerns motivated the creation of the European Banking Union. Precautionary recapitalization by a Member State is in some sense a relic from the time before Banking Union. One may therefore wonder whether the very general objective of remedying a serious disturbance to the economy of the Member State should really be taken to justify a precautionary recapitalization. Alternatively, one might think about lifting the competence for precautionary recapitalizations above the national level, for example to the level of the ESM.

One may also wonder about the appropriateness of the State aid procedure in this context. A major problem is that the State aid procedure takes time. During this time, the situation of the banks may worsen, the recapitalization needs may become larger, the bail-in-able creditors may run. In the case of Banca Popolare di Vicenza, a significant tranche of subordinated debt was due to be repaid on June 22, a few months after the application for the precautionary recapitalization and shortly before the decision on the application was to be taken. The payout was prevented by a last-minute decree of the Italian Parliament, but that raises questions of its own. For example, will the courts support the decree if the affected debt holders contest it?. After all, the debt holders had a legal claim, and the initiation of the procedure for a precautionary recapitalization had no effect on the legal status of that claim. If the courts do support such a decree, what will be the effects on the behavior of debt holders in future cases when a precautionary recapitalization is applied for? Will they not try to get out before another prohibition of payouts is decreed by the authorities? The very length of the State aid procedure in combination with the seeming arbitrariness of interim prohibitions of payouts may trigger some of the adverse reactions that a precautionary recapitalization might be claimed to forestall, in comparison to an insolvency procedure and even to a resolution procedure.

I may therefore be preferable to narrow the objectives mentioned in Article 32 (4) (d). The objective of preserving financial stability covers the major concern of maintaining important functions for the financial system. In a sense, this objective is also too broad because, as discussed in Section 2, some of the other concerns about systemic effects in the financial system can be addressed in resolution and do not necessitate a precautionary recapitalization.

The only function that may require a reference to more than financial stability is that of lending to the real economy. As discussed in Section 2.3, maintaining lending to the real economy does not necessarily suffer more harm under a resolution procedure than under a precautionary recapitalization. In fact, the only constellation where a precautionary recapitalization would be preferable with a view to maintaining lending to the real economy is when a large part of the banking system is affected and the resources available to the resolution authority are insufficient to handle a continuation of activities on such a scale. I suppose that this was true in the cases of Piraeus Bank and National Bank of Greece, though these cases were somewhat different anyway, because the banks' problems had a lot to do with the economic recession under the austerity regime and, moreover, the recapitalization was provided as part of the Third Debt Package, with funds coming from the European Stability Mechanism (ESM), rather than the Greek government.

Given that this was a very special constellation, it would make sense to replace the general reference to a serious disturbance in the economy by a more specific reference to the preservation of functions of the financial system to the real economy that may not be sustainable in resolution. It would also make sense to endow the Commission with the power to specify these functions in more detail than is warranted at the level of the Directive. Alternatively, as suggested above, one might think about raising this kind of precautionary recapitalization to the level of the ESM. In procedural terms, it might even then be preferable to involve the SRB right away. Once the resolution authority is 
involved, there would be no more questions as to whether limits on payouts to shareholders and debtholders can be imposed or not. Involving the resolution authority right away would also provide for some flexibility in the assessment whether a precautionary recapitalization is really needed to maintain lending and other functions or whether it is possible to provide for such continuity of functions merely by using the various resolution tools.

\subsection{The conditions for a precautionary recapitalization}

Under the Directive, a precautionary recapitalization must satisfy the following conditions:

- The institution must be solvent.

- The institution must not be failing or likely to fail in the sense of Article 32 (4) (a), (b), and (c) BRRD.

- The recapitalization must not provide the institution with an advantage.

- The recapitalization must not be used to offset losses that have occurred or are likely to occur in the near future.

- The measure must be of a temporary nature.

- The measure must be proportional to remedy the consequences of the serious disturbance.

- The recapitalization must be limited to what is needed to cover a capital shortfall established in stress tests and/or asset quality reviews of the ECB, EBA, or national authorities.

- The measure must be approved under the EU's State aid framework.

These conditions are intended to impose some discipline and some on precautionary recapitalizations and to prevent Member State governments from using these tools all too generously, with a potential for violating the rules of the Internal Market and/or damaging the viability of Banking Union and Monetary Union. The endeavor is very worthwhile, but even so, the conditions are somewhat problematic.

First, the restrictions that the BRRD imposes on a precautionary recapitalization can undermine the success of the operation. To see this, go back to the one clear example above where a precautionary recapitalization has substantial benefits over a resolution regime, a globally systemically important financial institution whose systemically important operations can only be maintained if the organization is kept intact, which is not possible under resolution with multiple points of entry. For such an institution, the arguments in favor of a precautionary recapitalization are independent of whether the institution is solvent or whether it satisfies one of the conditions for resolution.

As was discussed above, by mid-September 2008, doubts about the values of Lehman Brothers' assets were so great that short-term funding of the bank broke down and it was unable to meet its payment obligations. With a realistic valuation of mortgages in warehousing, Lehman Brothers was probably also insolvent. It thus failed two of the prerequisites for a precautionary recapitalization. Yet Lehman Brothers is the paradigmatic example of a globally systemically important financial institution for which a precautionary recapitalization would have to be much preferred to a resolution with multiple points of entry. The bank's entry in bankruptcy, even under the very borrower-friendly conditions of Chapter 11 of the US Bankruptcy Code, caused major damage to the global financial system.

Similarly, the conditions of temporariness and of proportionality and the limits imposed on the amount of the recapitalization can be counterproductive. Temporariness seems to preclude a recapitalization by means of common stock and to give preference to subordinated debt or (contingent) convertible debt, which can be repaid at some point. From the perspective of the other creditors of the bank, the injection of funds through such instruments provides for additional protection, just like a recapitalization through the issue of common stock. From the perspective of the bank's shareholders, the injection of funds through such instruments just adds to the amount of debt, i.e. of claims that take priority over payouts to shareholders. Incentive distortions from debt overhang 
are thus reinforced. Moreover, the ability and willingness of the bank to raise equity in the market is further reduced. ${ }^{18}$ With a contribution of common equity and a write-down of the existing equity, these distortions would be avoided but then the time horizon of the government's involvement is unbounded.

Proportionality and the limits imposed on the amount of recapitalization raise the possibility that the recapitalization will be insufficient to address the underlying problems of the bank. For example, a recapitalization that just meets a capital shortfall that has been established in a stress test or an asset quality review is too small if the valuation of the bank's assets has been overoptimistic. The three Italian banks, MPS, Banca Popolare di Vicenza and Veneto Banca, have all had previous recapitalizations, but these recapitalizations have only provided temporary relief. The idea of imposing limits on recapitalizations may have been to protect taxpayers from the costs of excessive recapitalizations, but insufficient recapitalizations that allow the bank to drag on while major problems persist can be much costlier. With all three banks, it probably would have been cheaper for taxpayers if the problems had been addressed and fully resolved when they first arose.

Second, the restrictions that the BRRD imposes on a precautionary recapitalization are unrealistic and to some extent mutually incompatible. If the bank "requires extraordinary public support", it is presumably unable to raise the funds on its own from investors. In such a situation, getting the funds from the government necessarily provides the bank with an advantage.

The condition that the recapitalization must not be used to offset losses that have occurred or are likely to occur in the near future is unrealistic. A bank that starts out being well capitalized will not need a recapitalization unless it makes losses in the interim. The shortfalls established in an asset quality review are the result of losses resulting from a revaluation of assets, e.g. loans where the review is more pessimistic about the prospect of recovery. This is in fact what happened with all five banks that have been involved in precautionary-recapitalization exercises. For the Italian banks, the comprehensive assessment of 2014 and the stress test of 2016 established capital shortfalls that were largely due to additional write-downs and provisions for non-performing loans. Similarly, for the Greek banks, the shortfalls established in 2015 had a lot to do with additional write-downs and provisions for non-performing loans in the wake of the 2015 crisis. In a sense therefore the calibration of recapitalizations to capital shortfalls established by stress tests and asset quality reviews is incompatible with the condition that recapitalizations must not be used to offset losses that have occurred or are likely to occur in the near future.

\subsection{The assessment of bank solvency}

Third, the requirement that the bank must be solvent has the problem that in practice, the determination of solvency is a matter of subjective judgement. This criticism also applies to the equivalent requirement that the bank must not have assets less than liabilities (Article 32 (4) (b) BRRD). Whether the bank is deemed to be solvent and whether the bank's assets are deemed to be greater than its liabilities depends on how the bank's assets are valued. For nontraded assets, however, such as loans, there is no universally valid "objective" valuation procedure. Whether the bank is deemed to be solvent depends on the likelihood one attaches to the borrowers' paying their dues or, in the aggregate, the share of borrowers whose loans are good. This assessment is a matter of judgment on which reasonable people can differ and on which unreasonable people will exhibit excessive optimism or excessive pessimism, as it suits their purposes.

In this context, it is worth noting that the capital shortfalls established by the responsible authorities have repeatedly undergone substantial changes over short periods of time. Greek banks passed the comprehensive assessment in 2014 without problems, were considered to solvent until June 2015, were considered to be insolvent in early July of 2015, and were considered solvent again a few month

${ }^{18}$ See Admati et al. (2018).

PE 602.089 
later. MPS was deemed to have a capital shortfall of $€ 5$ billion in the 2016 stress test and of $€ 8.8$ billion by December 2016, after the attempt to raise capital in the market had failed. Banca Popolare di Vicenza and Vento Banca were treated as solvent, merely in need of a precautionary recapitalization in one week and then as likely to fail and due to be wound down the next week. To the outsider, who Is not privy to the authorities' deliberations, such developments convey the impression that element of subjectivity which is necessarily present in any assessment of values of nontraded assets may by filled in by political considerations.

The intrusion of political considerations reinforces the danger, mentioned above, that precautionary recapitalizations limited to the capital shortfalls that have been established in stress tests and asset quality reviews may be too small restore the viability of the bank in question. An assessment of asset values that is influenced by the concern that the bank ought to be deemed solvent may be overoptimistic, in which case the capital shortfall that is established after the assessment may be smaller than what is really required to make the bank viable again.

As a rule, a bank's inability to raise equity in the market should be treated as prima facie evidence of insolvency. To understand this principle, it is useful to think about the market value of the bank's equity as consisting of the excess of the market value of its assets over the nominal value of its liabilities and of the value of the default option, i.e., the option of defaulting on creditors in the event of bankruptcy. After an equity issue, the value of the assets is increased by the proceeds of the issue. At the same time, the default option is devalued because the additional equity and the additional assets make a default less likely. However, the value of the default option is always positive, so the new market value of the equity after the equity issue is at least as large as the sum of the proceeds of the issue and the excess of the value of the bank's old assets over the liabilities. If the value of assets before the equity issue exceeds the liabilities, the value of the equity after the recapitalization is higher than the proceeds of the recapitalization, which means that there is some share price - and some degree of dilution of the old shareholders - at which the equity can be sold and the targeted proceeds achieved. Conversely, if it is not possible to raise new equity in the market, one may suppose that market investors attach such low values to the bank's assets that the assets are deemed to be worth less than the liabilities, a situation of insolvency. ${ }^{19}$

The argument here concerns the question whether the equity can be raised at any price at all, no matter how much of a dilution of old shareholders such a price may imply. In practice recapitalizations in the market may fail because the price at which the new shares are provided, e.g. in a rights offering, is too high. Incumbent shareholders will usually resist a recapitalization, and their resistance will be the stronger the more their position is being diluted. Whereas the recapitalization brings in additional funds that can be used to acquire additional return-bearing assets, the resulting increase in the value of the bank's assets is usually not large enough to compensate the old shareholders for the fact that their share in the bank is reduced. The reason is that, to some extent the additional assets benefit debt holders rather than shareholders as they make default and bankruptcy less likely. ${ }^{20}$

Given the resistance of incumbent shareholders to any recapitalization, the question is to what extent their attitudes should be allowed to influence the bank's behavior in a situation where its viability is in doubt. In the past, respect for the private property rights of incumbent shareholders has induced reluctance against diluting their positions. However, apart from issues of control related to the actual percentages of their shares, in terms of just the value of their shareholdings, the damage that a recapitalization does to the incumbent shareholders' wealth is entirely due to the devaluation of the

\footnotetext{
${ }^{19}$ Admati et al. (2013).

${ }^{20}$ This is the debt overhang effect of Myers (1977). For a systematic and general treatment, see Admati et al. (2018). Difficulties of firms in raising new equity are often also ascribed to asymmetric information, as in Myers and Majluf (1984). In contrast to debt overhang effects, however, the Myers-Majluf analysis is limited to market offerings. It does not extend to rights offering and the conclusions are reversed for increases in equity through retentions.
} 
default option as default is made less likely. I am wondering to what extent incumbent shareholders have a property right to the option that their bank defaults on promises to creditors that it has made.

\subsection{The role of the State aid framework}

The preceding concerns are linked to the role of State aid control in the present context. Recapitalizations and guarantees from Member State governments are of course a form of State aid and fall squarely into the domain of Article 107 TFEU. However, they are not the standard fare of State aid control. In the financial crisis, the Commission recognized this fact and adapted its handling of State aid for financial institutions by softening the conditions for supporting banks in that emergency. Subsequently, the Banking Communication made for a certain tightening again, in particular with respect to private-sector participation.

Throughout the crisis years, the Commission's control of bank rescue measures in the State aid framework has been very important as a way of imposing discipline on Member State governments and on banks, limiting tendencies to put in large sums of money in order to avoid having to lay ope the costs of insufficient supervision or of misguided industrial policy and to avoid losing banks as a source of para-fiscal funding for political projects outside the public budgets.

Despite these achievements, I have a sense that State aid control is not ideally suited to the problem at hand. In line with the Treaty, State aid control under Article 107 TFEU focuses on distortions of competition. When the predecessor of this article was introduced in the Treaty of Rome, the purpose was to prevent Member States from undermining the market opening that the Treaty provided by using public funds to promote "their" firms. This objective differs from the objective of preserving financial stability and containing systemic risk or from the objective of keep costs to taxpayer under control. Because financial stability, systemic risk and costs to taxpayers are not the primary focus of State aid control, there is a danger that measures undertaken in State aid control may sometimes be too strict and sometimes too lenient.

Examples of measures being potentially too strict for financial stability purposes have already been given in Section 4.2. Examples where State aid control is effectively too lenient typically involve banks that exit the market and are wound up. In the case of Banca Popolare di Vicenza and Vento Banca, once it was decided to liquidate the banks, the Italian government to was free to provide for bailouts of senior unsecured bondholders, which would not have been possible in resolution.

Other examples are provided by Hypo Real Estate and by HSH Nordbank in Germany. In the case of Hypo Real Estate, the transfer of assets at prices equal to nominal values into the government-owned asset management company FMS Wertmanagement involved State aid amounting $€ 16$ billion, which the Commission accepted because the German government owned both Hypo Real Estate and FMS Wertmanagement. The fact that this transfer made it possible to avoid winding Hypo Real Estate down and instead keep the bank in the market and later privatize it was not seen as a distortion of competition. In the case of HSH Nordbank, the bank must be privatized for a positive price or else wound down, presumably without much control over the distribution of losses between taxpayers and creditors. ${ }^{21}$ From a competition perspective such decisions are understandable but they are expensive for taxpayers.

In public discussion, concern for taxpayers has always appeared as a major rationale for the BRRD. However, among the objectives of resolution in the Directive, this concern is only one among several and it does not figure very prominently. Nor does it figure in Article 107 TFEU. It does figure in the Commission's Banking Communication of 2013, and the Court of Justice of the European Union has confirmed the legitimacy of this concern as a reason for imposing burden sharing in a case in precautionary-recapitalization cases. However, the argument given by the Court focuses on the

${ }^{21}$ For an account of both cases, see Hellwig (2017).

PE 602.089 
specific properties of equity and subordinated debt as securities where buyers know they are exposing to risk and do so because these securities offer higher returns on average, for example through a higher rate of interest on subordinated debt. This argument does not seem to apply to senior unsecured debt so, within the domain of State aid control, taxpayer concerns about the cost of a precautionary recapitalization seem are displaced by concerns about property rights of senior unsecured creditors. 


\section{CONCLUSIONS}

As assessed in this paper, the current system for dealing with problem banks suffers three major weaknesses. First, whereas for globally systemically important institutions a precautionary recapitalization has great advantages over a resolution regime with multiple points of entry, the restrictions imposed on precautionary recapitalizations may cause the handling of such institutions to be ineffective. Second, governments and supervisors seem to have incentives to delay interventions by not acknowledging problems soon enough. The delays allow the more professional subordinated creditors to exit early. When these creditors are replaced by unprofessional investors, including investors who are not well able to bear the risks that are involved, a bail-in of creditors becomes politically very more contentious. Concerns about such political fallout then create an additional motivation for further delay. In the case of the Italian banks, these delays have made the overall costs to taxpayers much higher than they would have been under a resolution procedure initiated, say for MPS in 2013 and for the other two banks in 2015. In each of these banks, the basic problems, in particular of nonperforming loans, were recognizable even then and were one reason why the institutional investors chose to withdraw. Third, the State aid procedure, while necessary to control abuse, is not well attuned to deal with the specific problems that arise in the financial sector. Given the focus on distortions of competition, financial stability concern and concerns about taxpayers may receive insufficient attention, in particular once it is decided to wind the institutions down so that they no longer matter for competition, except that a bailout of creditors of a bank in liquidation may create expectations about bailouts of creditors of other banks, which would then contribute to lowering funding costs of those other banks.

To address these weaknesses, the following concerns should be considered:

- Restricting the domain of precautionary recapitalization to globally systemically important financial institutions and, possibly, to situations where the maintenance of bank lending might overtax the resources of the resolution authority because too many banks are in trouble at the same time.

- Within the Banking Union, move the entire procedure to the European level, involving the ESM as well as the SRB. Addressing problems of globally systemically important financial institutions is of concern for all Member States of the Banking Union, not only the home country of the institution in question. For institutions that are not globally systemically important, but are under supervision by the Single Supervisory Mechanism, the matter is less clear, but even here the European responsibility for supervision, as well as the importance of the institutions for the transmission of the ECB's monetary policy would support a European responsibility for precautionary recapitalization as well as resolution and supervision.

- Provide the SRB with the powers, and possibly the resources, needed to ensure the maintenance of lending (as well as other systemically important functions) in resolution even if multiple banks are in crisis and, for lack of healthy banks, the sale-of-business/sale-of-asset tools are not very effective.

- Clarify the relation between objectives of interventions for dealing with banks in difficulties, in particular preservation of financial stability and reducing costs to taxpayers, and the objective of avoiding distortions to competition in the Internal Market, which is fundamental to the State aid framework.

- Give supervisory and resolution authorities incentives to avoid delays in recognizing solvency problems. In the United States, the 1991 Federal Deposit Insurance Corporation Improvement Act (FDICIA) provided such incentives for the FDIC by laying out an explicit scheme for prompt corrective action depending on the severity of the bank's problem; FDIC concerns about potential losses of the FDIC Deposit Insurance Fund added to the motivation to intervene early to avoid magnification of losses through delays.

These proposals are based on the observation that, on substantive grounds, the needs for precautionary recapitalizations can and should be much more narrowly defined than they currently are, also that the 
role of Member States, and the interplay between Member States and the Commission's State aid control contributes significantly to the delays. Member States are likely to resist the infringement of their sovereignty that is implied. However, some of the motivations that are involved, such as "saving" banks in order to maintain a flawed industrial policy, or a policy of financial repression that treats as parafiscal sources of funding for public purposes are highly problematic in a Banking Union and a Monetary Union whose functioning depends on banks being healthy and permitting a smooth transmission of monetary policy. 


\section{REFERENCES}

Admati, A.R., and M.F. Hellwig (2013), The Bankers' New Clothes, Princeton University Press, Princeton, N.J.

Admati, A.R., P.M. DeMarzo, M.F. Hellwig, and P.C. Pfleiderer, Fallacies, Irrelevant Facts, and Myths in the Discussion of Capital Regulation: Why Bank Equity is Not Socially Expensive, Preprint 23/2013, Max Planck Institute for Research on Collective Goods, Bonn, https://papers.ssrn.com/sol3/papers.cfm?abstract_id=2349739 .

Admati, A.R., P.M. DeMarzo, M.F. Hellwig, and P.C. Pfleiderer (2018), The Leverage Ratchet Effect, Max Planck Institute for Research on Collective Goods, Preprint 2013/13 (revised 2015), forthcoming, Journal of Finance, http://papers.ssrn.com/sol3/papers.cfm?abstract_id=2304969.

ASC (2012), Forbearance, resolution, and deposit insurance, Report 01/2012 of the Advisory Scientific Committee of the European Systemic Risk Board, https://www.esrb.europa.eu/pub/pdf/asc/Reports_ASC_1_1207.pdf?c4a55781325f99ef619100f7d2 $\underline{39321 \mathrm{a}}$

Bernanke, B. S. (1983), Nonmonetary Effects of the Financial Crisis in Propagation of the Great Depression, American Economic Review 73 (3), 257 - 276.

Bernanke, B.S. (1995), The Macroeconomics of the Great Depression: A Comparative Approach, Journal of Money, Credit and Banking 27, 1 - 28.

Born, K.E. (1967), Die deutsche Bankenkrise 1931, Piper Verlag, München.

Curry, T., and L. Shibut (2000), The Costs of the Savings and Loan Crisis: Truth and Consequences, FDIC Banking Review 13, 26 - 35.

Edwards, J., and K. Fischer (1994), Banks, Finance and Investment in Germany, Cambridge University Press

Englund, P. (1999), The Swedish Banking Crisis: Roots and Consequences, Oxford Review of Economic Policy 15, 80 - 97.

FCIC (Financial Crisis Inquiry Commission) (2011), The Financial Crisis Inquiry Report, Washington, D.C.

Friedman, M., and A.J. Schwartz (1963), A Monetary History of the United States, Princeton University Press, Preinceton, N.J.

Geithner, T. (2014), Stress Test: Reflections on the Financial Crisis, Random House, New York.

Harhoff, D., and T. Körting (1998), Lending Relationships in Germany - Empirical Evidence from Survey Data, Journal of Banking and Finance, 22, 1317-1353.

Hellwig, M.F. (2012), The Problem of Bank Resolution Remains Unsolved: A Critique of the German Bank Restructuring Law, in: P.S. Kenadjian (ed.), Too Big To Fail - Brauchen wir ein Sonderinsolvenzrecht für Banken?, De Gruyter Verlag, Berlin and Boston 2012, 35 - 63. 
Hellwig, M.F. (2014), Yes, Virginia, There is a European Banking Union! But it May Not Make Your Wishes Come True, Max Planck Institute for Research on Collective Goods, Bonn, Preprint 12/2014, http://papers.ssrn.com/sol3/papers.cfm?abstract_id=2487757

Hoshi, T.M., and A. Kashyap (2004), Japan's Financial Crisis and Economic Stagnation, Journal of Economic Perspectives 18 (Winter), 3 - 26.

Myers, S.C. (1977), Determinants of Corporate Borrowing, Journal of Financial Economics 5:147175.

Myers, S.C. and N.S. Majluf (1984), Corporate Financing and Investment Decisions when Firms Have Information that Investors Do Not Have, Journal of Financial Economics 13:187-222.

Weinstein, D., and Y. Yafeh (1998), On the Costs of a Bank-Centered Financial System: Evidence from the Changing Main Bank Relations in Japan, Journal of Finance 53, 635-672. 
\begin{tabular}{l|l} 
IPOL & DIRECTORATE-GENERAL FOR INTERNAL POLICIES
\end{tabular}

EGOV ECONOMIC GOVERNANCE SUPPORT UNIT

\section{Contact: egov@ep.europa.eu}

For more information: http://www.europarl.europa.eu/committees/en/ECON/home.html

PE 602.089

ISBN 978-92-846-1218-5 (paper)

ISBN 978-92-846-1217-8 (pdf)

doi:10.2861/040489 (paper)

doi:10.2861/727181 (pdf) 